\title{
ПОКРАЩЕННЯ ПРОФІЛАКТИКИ ВТОРИННОГО ІНФІКУВАННЯ ОПІКОВИХ РАН ПАЦІЄНТІВ З ТЕРМІЧНИМИ УШКОДЖЕННЯМИ ШКІРНИХ ПОКРИВІВ
}

\author{
๑О. Я. Попадюк, К. Б. Кіршак, М. М. Волошин \\ Івано-Франківський національний медичний університет \\ КНП «Обласна клінічна лікарня Івано-Франківської обласної ради»
}

РЕЗЮМЕ. Опікові пошкодження $є$ видом травматизму, що зустрічається на сьогодні найчастіше.

Мета - покращити профілактику вторинного інфікування у хворих із термічними опіками шкірних покривів I та Ila ступенів шляхом застосування сучасних інноваційних полімерних покриттів.

Матеріал і методи. В основу роботи покладені результати спостережень за 30 хворими з опіковими ураженнями шкірних покривів I та ІІа стадій. В основну групу входило 15 хворих, котрим при перев'язці додатково застосовували полімерні плівки, а у контрольній групі (15 хворих) використовували при перев'язці традиційні марлеві вологовисихаючі пов'язки. Застосована нами біодеградуюча полімерна плівка «Біодеп-нано» (Пат. № 110594 Україна, МПК 2016.01) у своєму складі містить желатин, полівініловий спирт, молочну кислоту, гліцерин та нанорозмірний оксид цинку (30 нм) й виготовляється як «Засіб гігієнічно-профілактичний. Біодеградуюча полімерна плівка «Біодеп-нано» 50 г згідно з ТУ У 20.4-2950221612-001:2017».

Результати. Отримані дані мікробіологічного дослідження продемонстрували, що у 14 хворих основної групи (93\%), рівень бактерій був нижче значення $10^{5}$ КУО/мл протягом усього терміну спостереження, що $\epsilon$ непатогенним значенням, рівень бактерій поступово зменшувався. У 1 хворого (7 \%) рівень висіяного St. Aureus був вище $16 \times 10^{5} \mathrm{KУO} / \mathrm{M}$.

Загоєння опіку І ст. у основній групі відбувалось на $(8,2 \pm 0,7)$ добу, а у контрольній групі - на $(10,5 \pm 1,4)$ добу, що обумовлено вторинним інфікуванням у контрольній групі. У пацієнтів з ІІа стадією опіку загоєння відбувалось на $(16,4 \pm 1,8)$ добу, а у пацієнтів з контрольної групи - на $(18,7 \pm 1,6)$ добу.

Висновок. Використання ранових покриттів на пінній основі, порівняно з використанням традиційного лікування, продемонструвало високу ефективність як у лікуванні, так і в профілактиці вторинного інфікування ран.

КлючОВІ СлОВА: опік; інфікування; рани; профілактика.

Вступ. Опікові пошкодження $\epsilon$ видом травматизму, що трапляється на сьогодні найчастіше. Дані статистичних показників, оприлюднені ВОО3 у 2015 році, демонструють, що кількість постраждалих з опіками, які потребували медичної допомоги, у світі становила 11 мільйонів осіб, що є четвертим за кількістю показником серед усіх травм. Кількість загиблих від опіків у 2016 році становила 300 тис. осіб (Bulletin of the World Health Organization) [1].

Крім медичного аспекту, опіки та пов'язані з ними естетичні зміни, рубці, контрактури та порушення, що обмежують функціонування, мають як психологічні та соціальні, так і економічні наслідки для пацієнтів, знижують їх шанси на економічно продуктивне життя в суспільстві [2].

Відомі на сьогодні загальноприйняті методи місцевого і хірургічного лікування, а також методи профілактики ймовірних ускладнень, $\epsilon$ недостатніми та не враховують сучасних можливостей. Розробка й початок застосування ранових покриттів започаткували нову еру в лікуванні опіків шкірних покривів $[3,4]$.

Нові тенденції місцевого лікування опікових ран продемонстрували, що вологовисихаючі марлеві пов'язки не забезпечують пролонгованого лікувального ефекту, не захищають рану від ви- сихання, потрапляння інфекції ззовні чи впливу інших факторів наколишнього середовища, на відміну від сучасних ранових покриттів [5].

Для контролю та боротьби з інфекцією у ранах застосовують як хірургічні методи, а саме висічення некротизованихтканин,такіперев'язувальні засоби, що мають протимікробні властивості. До таких ранових покриттів належать: ліофілізовані ксенотрансплантати, гідрогелеві покриття, а також покриття, насичені іонами металів, плівкові і пінополіуретанові покриття, покриття з клітинним компонентом тощо $[6,7]$.

Інноваційні ранові покриття можуть застосовуватись не тільки в I чи ІІ стадіях ранового процесу, як засоби очищення некротичних тканин, а й в III стадії, як засіб захисту ран [8].

Наприклад, гідрогелеві пластирі для місцевого лікування опіків "DermaPlast» $\mathrm{i}$ «Urgo Burns» та "Versiva XС" виробництва фірми "Bristol Myers Squibb" $\epsilon$ композиціями з природних і синтетичних полімерів, і, згідно з інструкцією до застосування, належать до безрецептурних лікувальних засобів та можуть використовуватись у лікуванні поверхневих і глибоких опіків (II-ІІІ ступенів) [9].

Дермальні поверхневі опіки загоюються самостійно протягом трьох тижнів. Дермальні глибокі, обмежені за площею опіки, можуть загоїтися про- 
Огляди літератури, оригінальні дослідження, погляд на проблему, випадок з практики, короткі повідомлення тягом чотирьох тижнів чи впродовж довшого строку, або потребувати хірургічного лікування. У $60 \%$ постраждалих із дермальними опіками після загоєння залишаються патологічні рубці, які потребують тривалого консервативного та хірургічного лікування [10].

Мета - покращити профілактику вторинного інфікування у хворих із термічними опіками шкірних покривів I та ІІа стадій шляхом застосування сучасних інноваційних полімерних покриттів.

Матеріал і методи дослідження. В основу роботи покладені результати спостережень за 30 хворими з опіковими ураженнями шкірних покривів I та ІІа стадій. Хворі були госпіталізовані в опікове відділення Івано-Франківської ОКЛ у 2019 році. Вік пацієнтів з термічними ураженнями шкірних покривів коливався від 27 до 67 років, а ділянки ураження були площею від 4 \% до $12 \%$. Серед них чоловіків було 18 (60\%), жінок - 12 (40\%). Середній вік хворих склав 47,7 років - найстаршому було 67 років, наймолодшому - 27.

До основної групи увійшли 15 хворих, яким при перев'язці додатково застосовували полімерні плівки, а до контрольної групи - 15 хворих, яким використовували традиційні марлеві вологовисихаючі пов'язки.

Перед застосуванням полімерної плівки у пацієнтів отримували дозвіл на їі зовнішнє застосування в процесі перев'язок з метою профілактики вторинного інфікування.

Застосована нами біодеградуюча полімерна плівка «Біодеп-нано» (Пат. №110594 Україна, МПК 2016.01,) у своєму складі містить желатин, полівініловий спирт, молочну кислоту, гліцерин та нанорозмірний оксид цинку (30 нм) і виготовляється як «Засіб гігієнічно-профілактичний. Біодеградуюча полімерна плівка «Біодеп-нано» 50 г згідно з ТУ У 20.4-2950221612-001:2017». Плівки накладали під марлеву пов'язку та замінювали через 2 доби, до 21-ї доби, з оцінкою стану поверхні опіку та наявності чи відсутності патологічних реакцій чи гнійних виділень.

Статистичну обробку даних проводили з використанням t-критерію Стьюдента, $5 \%(p \leq 0,05)$.

Результати й обговорення. У 5 хворих (33\%) основної групи був опік I стадії, а у 10 хворих (67\%) - опік ІІа стадії; у 6 хворих (40\%) контрольної групи був опік I стадії, у 9 хворих (60\%) - опік Ila стадії. Застосування плівки розпочинали у хворих з І стадією опіку на 2-гу добу, а у пацієнтів з ІІа стадією на 9 добу.

Отримані дані мікробіологічного дослідження продемонстрували, що у 14 (93\%) хворих основної групи рівень бактерій був нижчим $10^{5} \mathrm{KУO} / \mathrm{Mл} \mathrm{про-}$ тягом усього терміну спостереження, що $\epsilon$ непатогенним значенням. У цій групі рівень бактерій поступово зменшувався, але у 1 (7 \%) хворого рівень висіяного St. Aureus перевищував $16 \times 10^{5}$ КУО/мл.

У групі порівняння у 6 хворих рівень бактеріального забруднення перевищував значення $10^{5} \mathrm{KУO} / \mathrm{мл.} \mathrm{У} \mathrm{цих} \mathrm{хворих} \mathrm{у} \mathrm{трьох} \mathrm{випадках} \mathrm{була} \mathrm{ви-}$ сіяна E.Coli, у 2 хворих був висіяний стрептокок, що вказує на вторинне інфікування опікової ділянки.

Загоєння опіку І ст у основній групі відбувалось на $(8,2 \pm 0,7)$ добу, а у контрольній групі - на $(10,5 \pm 1,4)$ добу, що обумовлено вторинним інфікуванням у контрольній групі. У пацієнтів з ІІа стадією опіку загоєння відбувалось на $(16,4 \pm 1,8)$ добу, а у пацієнтів з контрольної групи - на $(18,7 \pm 1,6)$ добу.

Слід зазначити, що плівка еластична, м'яка на дотик та легко набуває форми ділянки тіла з опіком. Це забезпечує добрий контакт із пошкодженою ділянкою та захист від потрапляння інфекції ззовні. Крім того, було відмічено, що плівка надійно захищає ділянку опіку від зовнішніх подразників. У всіх випадках в основній групі, після застосування плівки пацієнти вказували на відсутність подразнень чи болю у ділянці опіку при контакті чи на перев'язці, на відміну від контрольної групи, 8 пацієнтів якої скаржилися на дискомфорт та подразнення в ділянці ушкодження.

Результати мікробіологічного дослідження мазків, взятих з опікової ділянки, показали, що протягом усього терміну застосування рівень патогенної флори в основній групі знаходився на рівні, що значно нижчий за показник $10^{5} \mathrm{KУO/мл}$ на відміну від контрольної групи, де у 4 випадках рівень патогенної флори перевищував показник $10^{5} \mathrm{KУO} / \mathrm{Mл,} \mathrm{що} \mathrm{візуально} \mathrm{проявлялося} \mathrm{вираже-}$ ною гіперемією опікової поверхні з запальним валиком по периферії.

Свідченням позитивного ефекту від застосування полімерних покриттів у веденні опікових ран $\epsilon$ оприлюднені у літературі результати вивчення впливу ранових покриттів на рН вмісту ран у потерпілих з поверхневими опіками шкіри. Встановлено, що застосування ранових покриттів приводить до зміни лужного середовища на кисле у рані, що, в свою чергу, стимулює процеси загоєння та епітелізації ран [5].

Результати досліджень, наведені у наукових джерелах, свідчать, що використання ранових покриттів на пінній основі, порівняно з використанням традиційного лікування, $\epsilon$ високоефективним як у лікуванні, так і в профілактиці вторинного інфікування ран [11].

Підтвердження отриманих нами результатів знаходимо у результатах досліджень закордонних науковців, котрі застосували гелеутворювальні плівки у 113 хворих при опіках II та III стадій та довели високу ефективність їх застосування. Досліджувані покриття виявили такі позитивні власти- 
Огляди літератури, оригінальні дослідження, погляд на проблему, випадок з практики, короткі повідомлення

вості: виражена адгезія та фіксація та шкірних покривах; виражені сорбційні властивості, що перевищують за цим показником традиційне застосування марлевих пов'язок; зменшення кількості перев'язок; еластичність; щільність, що забезпечує захист та запобігає проникненню мікрофлори з3овні [12].

Висновки. 1. Застосування біодеградуючої полімерної плівки "Біодеп-нано" у пацієнтів з опіками I та II стадій в якості допоміжного профілактичного засобу для зовнішнього застосування $\epsilon$ виправданим, високоефективним сучасним способом захисту ділянки опіку від вторинного інфікування, що сприяє швидшому загоєнню пошкодженої ділянки та зменшує час перебування хворого в стаціонарі.

\section{ЛІТЕРАТУРА}

1. WHO. BURNS http:// www.who.int/en/news-room/ fact sheets/detail/burns.

2. Peck Michael D. Epidemiology of burns throughout the world. Part I: Distribution and risk factors / Michael D. Peck // Burns. 2011. - No. 37 (7). - P. 1087-1100.

3. Herndon D. N. Total burn care / D. N. Herndon. Saunders, Philadelphia PA: Hardcover, 2012. - 808 p.

4. Козинець Г. П. Нова концепція розвитку комбустіологічної служби в Україні / Г. П. Козинець, М.П.Комаров, А. В. Воронін // Вестник неотложной и восстановительной медицины. - 2014. - № 1, Т. 15. - С. 6-8.

5. Коваленко О. М. Вплив ранових покриттів на $\mathrm{Ph}$ рани при поверхневих опіках шкіри / О. М. Коваленко, А. О. Коваленко, О. І. Осадча // Клінічна хірургія. 2017. - № 2. - C. 28-30.

6. Supp D. M. Skin substitutes for burn wound healing: current and future approaches / D. M. Supp // Expert Review of Dermatology. - 2011. - Vol. 6. - P. 217-227. DOI: $10.1586 /$ edm.10.73.

7. Еремеев С. А. Клиническая оценка эффективности использования серебросодержащих раневых покрытий при лечении пострадавших с 164 поверхностными ожогами / С. А. Еремеев, О. В. Чивков, А. В. Коваленко // Вестник Новгородского гос. университета. - 2012. - № 66. С. 41-45.

\section{REFERENCES}

1. WHO. BURNS http:// www.who.int/en/news-room/ fact sheets/detail/burns.

2. Peck, Michael, D. (2003). Epidemiology of burns throughout the world. Part I: Distribution and Risk Factors, 37 (7), 1087-1100.

3. Herndon, D.N. (2012). Total Burn Care (4 th). Saunders, Philadelphia PA. Hardcover ISBN: 9781437727869.

4. Kozynets, H.P., Komarov, M.P., \& Voronin, A.V. (2014). Nova kontseptsiia rozvytku kombustiolohichnoi sluzhby v Ukraini [A new concept for the development of combustion service in Ukraine.] Vestnik neotlozhnoy $i$ vosstanovitelnoy meditsinyi - Herald of Emergency and Restorative Medicine, 1 (15), 6-8 [in Ukrainian].
2. Біодеградуюча полімерна плівка «Біодепнано» $є$ сучасним профілактичним засобом для зовнішнього застосування, відповідає сучасним вимогам до ранових покриттів, $є$ перспективним для застосування в хірургії, зокрема в комбустіології.

Перспективи подальших досліджень. Удосконалення, розробка та застосування заходів запобігання вторинному інфікуванню дермальних опіків I, II стадій, в подальшому і III стадії, на основі використання місцевих інноваційних засобів у вигляді плівок дозволить підвищити ефективність профілактики, лікування, покращить якість проведення перев'язок та зменшить час перебування пацієнтів з опіковими ураженнями в стаціонарі.

8. Юрова Ю. В. Объективные критерии готовности пациентов с гранулирующими ожоговыми ранами к свободной аутодермопластике / Ю. В. Юрова, И. В. Шлык, П. К. Крылов // Вестник хирургии имени И. И. Грекова. 2015. - C. 57-62. https://doi.org/10.24884/0042-4625-2015 $-174-2-57-62$.

9. Вонс Б. В. Проблема лікування опікових травм i характеристика лікарських засобів для місцевого лікування опіків / Б. В. Вонс, М. Б. Чубка, Т. А. Грошовий // Актуальні питання фармацевтичної і медичної науки та практики. - 2018. - Т. 11, № 1 (26). - С. 119-125.

10. Вплив хірургічного лікування дермальних опіків на природну резистентність і розвиток рубців / А. О. Коваленко, Г. П. Козинець, О. М. Коваленко, О. І. Осадча // Пластична, реконструктивна і естетична хірургія. -2018.№ 1-2. - С. 48-60.

11. Быстров С. А. Лечение гнойных ран с применением раневых покрытий на пенной основе с технологией Гидрофайбер / С. А. Быстров, А. И. Безбородов, С. Е. Каторкин // Хирургия. - 2017. - № 7. - С. 49-53.

12. Куранов А. А. Использование пенополиуретановой повязки II поколения при ожогах / А. А. Куранов, А. В. Сорокин, Е. Ю. Игнатов // Кубанский научный медицинский вестник. - 2012. - № 2 (131). - С. 115-119.

5. Kovalenko, O.M., Kovalenko, A.O., \& Osadcha, O.I. (2017). Vplyv ranovykh pokryttiv na Ph rany pry poverkhnevykh opikakh shkiry [Influence of wound coatings on $\mathrm{Ph}$ wounds in skin surface burns]. Klinichna khirurhiia-Clinical Surgery, 2, 28-30 [in Ukrainian].

6. Supp, D.M. (2011). Skin substitutes for burn wound healing: current and future approaches. Expert Review of Dermatology, 6. 217-227. doi: 10.1586/edm.10.73.

7. Eremeev, S.A., Chyvkov, O.V., \& Kovalenko, A.V. (2012). Klinicheskaya otsenka effektivnosti ispolzovaniya serebrosoderzhaschih ranevykh pokrytiy pri lechenii postradavshikh s 164 poverhnostnymi ozhogami [Clinical evaluation of the effectiveness of using silver-containing wound dres- 
Огляди літератури, оригінальні дослідження, погляд на проблему, випадок з практики, короткі повідомлення sings in the treatment of patients with 164 superficial burns]. Vestnik Novgorodskogo gos. universiteta - Bulletin of the Novgorod State University, 66, 41-45 [in Russian].

8. Yurova, Yu.V., Shlyk, I.V., \& Krylov, P.K. (2015). Obyektivnyye kriterii gotovnosti patsientov s granuliruyushchimi ozhogovymi ranami k svobodnoy autodermoplastike [Objective criteria for the readiness of patients with granular burn wounds for free autodermoplasty]. Vestnik khirurgii imeni I.I. Grekova - Herald of Surgery named after I.I. Grekov, 174 (2), 57-62. Retrieved from: https://doi. org/10.24884/0042-4625-2015-174-2-57-62 [in Russian].

9. Vons, B.V., Chubka, M.B., \& Hroshovyi, T.A. (2018). Problema likuvannia opikovykh travm i kharakterystyka likarskykh zasobiv dlia mistsevoho likuvannia opikiv [The problem of treatment of burn injuries and the characteristics of drugs for local treatment of burns.]. Aktualni pytannia farmatsevtychnoi i medychnoi nauky ta praktyky - Topical Issues in Pharmaceutical and Medical Science and Practice, 1 (26), 119-125 [in Ukrainian].

10. Kovalenko, A.O., Kozynets, H.P., Kovalenko, O.M., \& Osadcha, O.I. (2018) Vplyv khirurhichnoho likuvannia dermalnykh opikiv na pryrodnu rezystentnist i rozvytok rubtsiv [The impact of surgical treatment of dermal burns on natural resistance and scarring]. Plastychna, rekonstruktyvna $i$ estetychna khirurhiia - Plastic, Reconstructive and Aesthetic Surgery, 1-2, 48-60 [in Ukrainian].

11. Bystrov, S.A., Bezborodov, A.I., \& Katorkin, S.E. (2017). Lechenie gnoynykh ran s primeneniem ranevykh pokrytiy na pennoy osnove s tekhnologiey Gidrofayber [Treatment of purulent wounds using wound dressings on a foam basis with Hydrofiber technology]. Khirurgiya - Surgery, 7, 49-53 [in Russian].

12. Kuranov, A.A., Sorokin, A.V., \& Ignatov, E.Yu. (2012). Ispolzovanie penopoliuretanovoy povyazki II pokoleniya pri ozhogakh [The use of a polyurethane foam bandage of the second generation for burns]. Kubanskiy nauchnyy meditsinskiy vestnik - Kuban Scientific Medical Bulletin, 2 (131), 115-119 [in Russian].

\title{
УЛУЧШЕНИЕ ПРОФИЛАКТИКИ ВТОРИЧНОГО ИНФИЦИРОВАНИЯ ОЖОГОВЫХ РАН ПАЦИЕНТОВ С ТЕРМИЧЕСКИМИ ПОВРЕЖДЕНИЯМИ КОЖНОГО ПОКРОВА
}

\author{
๑А. Я. Попадюк, К. Б. Киршак, М. М. Волошин \\ Ивано-Франковский национальный медицинский университет \\ КНП «Областная клиническая больница Ивано-Франковского областного совета»
}

PЕЗЮмЕ. Ожоговые повреждения являются видом травматизма, встречающимся сегодня чаще всего.

Цель - улучшить профилактику вторичного инфицирования у больных с термическими ожогами кожных покровов I и ІІа степеней путем применения современных инновационных полимерных покрытий.

Материал и методы. В основу работы положены результаты наблюдений за 30 больными с ожоговыми поражениями кожных покровов I и ІІа стадий. В основную группу входило 15 больных, которым при перевязке дополнительно применяли полимерные пленки, а в контрольной группе (15 больных) использовали при перевязке традиционные марлевые влажновысыхающие повязки. Примененная нами биоразлагаемая полимерная пленка «Биодеп-нано» (Пат. № 110594 Украина, МПК 2016.01) в своем составе содержит желатин, поливиниловый спирт, молочную кислоту, глицерин и наноразмерный оксид цинка (30 нм) и изготавливается как «Средство гигиеничнопрофилактическое. Биоразлагаемая полимерная пленка «Биодеп-нано» 50 г по ТУ У 20.4-2950221612-001: 2017».

Результаты. Полученные данные микробиологического исследования показали, что у 14 больных основной группы (93 \%) уровень бактерий был ниже значения $10^{5} \mathrm{KOE} /$ мл в течение всего срока наблюдения, что является непатогенным значением, уровень бактерий постепенно уменьшался. У 1 больного (7 \%) уровень высеянных St. Aureus был выше $16 \times 10^{5} \mathrm{KOE} / \mathrm{Mл}$.

Заживление ожога I ст. в основной группе происходило на $(8,2 \pm 0,7)$ сутки, а в контрольной группе - на $(10,5 \pm 1,4)$ сутки, что обусловлено вторичным инфицированием в контрольной группе. У пациентов с ІІа стадией ожога заживление происходило на $(16,4 \pm 1,8)$ сутки, а у пациентов контрольной группы - на $(18,7 \pm 1,6)$ сутки.

Вывод. Использование раневых покрытий на вспененной основе, по сравнению с использованием традиционного лечения, продемонстрировало высокую эффективность как в лечении, так и в профилактике вторичного инфицирования ран.

КЛЮЧЕВЫЕ СЛОВА: ожог; инфицирование раны; профилактика.

\section{IMPROVING THE PREVENTION OF SECONDARY INFECTION OF BURN WOUNDS IN PATIENTS WITH THERMAL DAMAGE TO THE SKIN}

\author{
๑O. Ya. Popadyuk, K. B. Kirshak, M. M. Voloshyn \\ Ivano-Frankivsk National Medical University
}

Municipal Non-profit Enterprise "Regional Clinical Hospital of Ivano-Frankivsk Regional Council"

SUMMARY. Burn injuries are the type of injury that occur most often today.

The aim - to improve prevention of secondary infection in patients with first and second degrees thermal burns of skin cover by applying modern innovative polymer coatings. 
Огляди літератури, оригінальні дослідження, погляд на проблему, випадок з практики, короткі повідомлення

Material and Methods. The results of observations of 30 patients with first and second degree burns of the skin are based on the work. The main group consisted of 15 patients, who additionally used polymer films in the dressing, and in the control group (15 patients), traditional gauze-wet dressings were used in the dressing. We applied biodegradable polymer film "biodep-nano" (Pat. No. 110594 Ukraine, IPC 2016.01,), in its composition contains gelatin, polyvinyl alcohol, lactic acid, glycerol and nanoscale zinc oxide $(30 \mathrm{~nm})$ and is manufactured as "Hygiene agent". preventive. Biodegradable polymer film "Biodep-nano" $50 \mathrm{~g}$ according to TU 20.4-2950221612-001: 2017 ".

Results and Discussion. The microbiological data obtained showed that in 14 patients of the main group $93 \%$, the bacterial level was lower than $105 \mathrm{CFU} / \mathrm{ml}$ during the whole observation period, which in turn is non-pathogenic, the bacterial level gradually decreased, in the first patient $7 \%$ the level of sown St. Aureus was above $16 \times 10^{5} \mathrm{CFU} / \mathrm{ml}$.

Healing of the first degree burn in the main group occurred on $(8.2 \pm 0.7)$ days, and in the control group on $(10.5 \pm 1.4)$ days, which was caused by secondary infection in the control group. In patients with second degree burn healing occurred at $(16.4 \pm 1.8)$ days, and in patients with the control group at $(18.7 \pm 1.6)$ days.

Conclusion. Research results from scientific sources have shown that the use of foam-based wound coatings, compared with the traditional use of traditional treatment, has demonstrated the high effectiveness of such techniques in the treatment and prevention of secondary wound infection.

KEY WORDS: burns; infections; wounds; prevention. 